\title{
IMPORTANCE OF HISTORICAL AND CULTURAL PERSPECTIVES (AN EXAMPLE OF ROMANCE VARIETIES)
}

\author{
Aleksandra Banjević, University of Montenegro, ab@t-com.me \\ 10.31902/fll.25.2018.2 \\ UDK 81'246.3
}

\begin{abstract}
Language contacts can be studied in three directions: language acquisition; b) language borrowing; c) translation. In this project all the three directions are investigated. The process of language borrowing is analysed on four levels: phonological, morphological, semantic, and syntactic. The adaptation of a model (a foreign word) shows two kinds of changes, primary and secondary changes, which take place on all four levels. The adaptation on the quoted levels is carried out according to the three types of transphonemization (zero, compromise and free) and according to the degree of the change of meaning on the semantic level.
\end{abstract}

Keywords: languages in contact, linguistic borrowing, primary and secondary adaptation, indirect borrowing, direct borrowing, foreign word, foreign loan, loan-word.

Contacts between languages are always the result of historical and cultural relations. To understand the full importance of these influences, we should consider the synchronic and diachronic dimensions of languages. At any stage of its development, language is the result of historical processes, which determine its structure and features. The processes of language contacts can lead to different results ranging from lexical borrowing, different influences on language structure, to the extensive structural borrowing which, eventually, leads to typological changes because of the loss of phonological oppositions, as well as to categorical changes in the field of morphosyntax, etc (Thomson \& Kaufman, 1991). The most common form in which aloglotic influences are manifested is lexical borrowing. The recent research of Dalmatian has been limited by the available material. Nevertheless, it is of great interest for Romance studies, not only because of its destiny (the last speaker of vegliot dialect died on Krk at the end of XIX century), but especially because of the influence of the Venetian, North Italian dialect. For us, therefore, the study of this language will illuminate the impact of the Romance languages on coastal dialects in Montenegro.

Every language is susceptible to the influences of other languages. Some words taken from other languages ephemerally stay 
in the recipient language and after a while disappear, while some other words taken from other languages become an integral part of the vocabulary to the extent that people who use these words do not feel them as words of foreign origin. Interlingual lexical influences are not only important for linguistics but also for the humanities. They are talking about the nature of the relationships between different languages and civilisations. Beside the communication function, language also has the symbolic function through which it becomes a symbol of the community, a symbol of national, cultural and religious identity.

In addition to the basic lexical fund of Slovenian origin, Montenegrin also contains lexical layers from other languages. Throughout its development, the Montenegrin language has taken words from Greek, Latin, Turkish, Italian, French, Russian, German... Loanwords are seen as a testimony to historical trends and contacts between cultures. The majority of loanwords that belong to the corpus of standard language are different terms, mostly connected with music, art, banking, cookery etc., which have been entering the Montenegrin language directly or indirectly, through other languages.

These lexical influences were gradual and uneven, and conditioned by historical and cultural circumstances. According to Bloomfield, cultural borrowing is the taking over of words for new things and concepts, while intimate borrowing is the using of two or more languages in the same area or within the same political community, whereby the socalled "higher" language becomes the source of the borrowing process for the language whose sociolinguistic status is lower. Recently, Carol Mayers-Scotton has introduced a similar distinction using the terms cultural and "thorough" borrowing. Cultural borrowing fills the lexical gaps in the recipient language, while thorough borrowing frequently takes over words for which domestic equivalents exist, eventually leading to the relexification - the replacement of the domestic fund of the words with the foreign fund.

Unlike cultural borrowing, which usually takes place in written form, intimate borrowing develops in oral discourse. While cultural borrowing only affects the periphery of the language system, intimate borrowing can affect all aspects of the language system including phonology, syntax, and morphology. On the synchronic level, contacts between languages can lead to the variations in language, whereas massive language changes are produced when languages meet on the diachronic level.

Numerous linguistic phenomena such as convergence, borrowing, code-switching etc. are present throughout the history of 
Montenegrin-Romance contacts. Adriatic Romans were carriers of urban continuity; making the connection between the coastal belt and the Euro-Mediterranean space. The Dalmatian language disappeared because of the effects of Slovenian adstrata and due to the convergence with the cognate Romance idiom - Venetian. During four centuries of continuous power, Venetian was the language of administration, trade and navigation. Since Venetian was in constant contact with other languages in the Mediterranean, it was closely related to multilingualism. Taking over Greek terms, Venetianisms entered many other languages in large numbers. Furthermore, Venetian functioned as a basis of linguae Francae in the Mediterranean for centuries.

The basic form of replica is determined in the process of morphological adaptation by adjusting to the morphological system of the recipient language whereby three levels of transformation occur: zero, compromise and complete transformation. The difference between two types of borrowing is particularly expressed at the semantic level. The majority of Italianisms are technical terms from the field of music, literature, trade, banking etc. There are numerous loanwords which mark abstract terms, states of mind, character traits, and so on. Although the main motive for the borrowing of foreign words is meaning, semantic aspect has been the least explored part of the general problem of lexical borrowing. The available research emphasizes the problem related to loanwords and their identification.

The type of loanwords determines the specificities that occur during the process of semantic adaptation. In the phase of primary adaptation, numbers and fields of meaning are narrowed. In the phase of secondary adaptation, meaning of some loanwords is extended under the influence of various factors, such as metaphor, ellipsis, metonymy etc. Sometimes the same loanword has different meanings. Thus, "credit," means both "loan" and "trust."

The process of integration of a foreign word is carried out in several phases and from two points of view, that of the encoder and that of the decoder. This process lasts from the appearance of the foreign word to its complete codification. In the first phase, the speaking subject who uses the foreign word is completely aware that the word presents an unknown element within the language and she/he feels the need to explain this in order to make the assertion understandable. Metalinguistic use of words and phrases very often takes place in this phase. In this phase we are not yet sure whether the foreign word will become a loanword, i.e. whether it will be accepted. In the second phase, the foreign word is not a completely strange 
element in language. Yet, while its interpretation does not usually follow its use, the foreign word is still not felt completely integrated. In the third phase we can talk about loanwords. We do not hesitate anymore to use the foreign word or to stand it out graphically. The loanword is phonologically, morphologically, and semantically adapted and completely codified in the recipient language.

We should also point out the difference between xenism and a loanword. Xenism is a foreign word that marks non-linguistics reality which does not exist in the experience of the recipient nation. Xenisms are words without a referent in the recipient language or the words that reflect special characteristics of some national, folklore, or local colour. We cannot translate xenisms because they lose some essential semantic or connotative attributes in translation. Therefore, we can find inappropriate translations or lexicographic definitions in the dictionaries. For example, if we translated bukinist as antiquarian we would be making a mistake, if we gave its original definition - "second hand books seller" - we would lose local colour. Therefore, xenism is a foreign word, which is not completely integrated in the recipient language, since it does not have an adequate referent. However, when the referent occurs xenism easily becomes a loanword.

Despite criticism of the division into denotative and connotative loanwords, a common comparison will show that some words are borrowed to satisfy completely determined lexical needs and that they do not have appropriate replacements in the recipient language. Other words have replacements in the recipient language and are borrowed for some other reasons. Very often these loanwords evoke civilisation and culture of the donor language.

It often happens today that the use of foreign words is instructed by snobbism. Besides, foreign words that have domestic equivalents frequently function as euphemisms or they can be used with pejorative connotations. Therefore, a very important factor for the integration of words of foreign origin is their semantic relation with domestic words. Making their place in the lexical-semantic system of the recipient language, loanwords enter very complex structural relations with domestic words and their integration depends on the stability of theserelations.

We have seen that, as a solely human phenomenon, language is always a part of a shared inheritance. Therefore, studying one language inevitably subsumes studying the unique culture that both enables the development of language and is, in turn, determined by it. It is the understanding of subtle cultural changes, the knowledge of the history of the people whose language is the primary object of our 
studies, as well the nature in which the historical changes take place and reasons for the changes, which give us a complete grasp of the language that is spoken, of the semantic choices it makes, as well as of the logic its sentences develop in.

\section{References:}

Bammesberger, A. \& T. Vennemann (eds.). Languages in Prehistoric Europe, Winter, Heidelberg, 2001.

Filipović, R. Teorija jezika u kontaktu. Uvod u lingvistiku jezičnih dodira. ŠK-JAZU, Zagreb, 1986.

Filipović, R. Anglicizmi u hrvatskom ili srpskom jeziku. Porijeklo - razvoj - značenje, ŠK-JAZU, Zagreb, 1990.

Jernej, J. Sugli italianismi penetrati nel serbo-croato negli ultimi cento anni. Studia romanica, 1/1, Zagreb, 54-82.

Kovačec, A. Bilingvizam i aloglotski utjecaji na morfosintaktičku strukturu jezika. Suvremena lingvistika 4, Zagreb, 1967, 101114.

Schneeweis, E. Die deutsche Lehnwörter im Serbokroatischen, Berlin, 1960.

Skok, P. Prilog metodi proučavanja romanizama u hrvatskom ili srpskom jeziku, Zbornik radova Filozofskog fakulteta I, Zagreb, 1951, 445-485.

Striedter-Temps, H. Deutsche Lehnwörter im Serbokroatischen, Wiesbaden, 1958.

Weinreich, U. Languages in Contact (various editions), Zbornik Zagrebačke slavističke škole. Zagreb, 2001, 105-190.

\section{JEZIČKO POZAJMLIVANJE U BILINGVALNOM KONTEKSTU (NA PRIMJERU ROMANSKIH VARIJETETA)}

Jezički dodiri se proučavaju u tri smjera: a) usvajanje jezika, b) jezičko posuđivanje, c) prevođenje.

Proces jezičkog posuđivanja analizira se na četiri nivoa: fonološkom, morfološkom, semantičkom i sintaksičkom.

Adaptacija modela pokazuje primarne i sekundarne pojave koje se javljaju na sva četiri nivoa. Adaptacija prema nivoima vrši se prema tipovima transfonemizacije, transmorfemizacije i stepenima promjene značenja na semantičkom nivou. 
Ključne riječi: jezici u kontaktu, jezičko posuđivanje, primarna i sekundarna adaptacija, posredno posuđivanje, neposredno posuđivanje, strana riječ, tuđica, posuđenica. 